Licaria caribaea (Lauraceae): A New Species from the Caribbean Lowlands of Costa Rica Author(s): Jorge Gómez-Laurito and Alfredo Cascante

Source: Novon, Vol. 9, No. 2 (Summer, 1999), pp. 199-201

Published by: Missouri Botanical Garden Press

Stable URL: http://www.jstor.org/stable/3391798

Accessed: 14/11/2013 13:59

Your use of the JSTOR archive indicates your acceptance of the Terms \& Conditions of Use, available at http://www.jstor.org/page/info/about/policies/terms.jsp

JSTOR is a not-for-profit service that helps scholars, researchers, and students discover, use, and build upon a wide range of content in a trusted digital archive. We use information technology and tools to increase productivity and facilitate new forms of scholarship. For more information about JSTOR, please contact support@jstor.org. 


\title{
Licaria caribaea (Lauraceae): A New Species from the Caribbean Lowlands of Costa Rica
}

\author{
Jorge Gómez-Laurito \\ Escuela de Biología, Universidad de Costa Rica, Ciudad Universitaria 2060, \\ San José, Costa Rica
}

Alfredo Cascante

Herbario Nacional de Costa Rica, Museo Nacional, Ap. 749-1000 San José, Costa Rica

Abstract. A new Licaria (Lauraceae) from the Caribbean lowlands of Costa Rica is described and illustrated here.

RESUMEN. Una Licaria (Lauraceae) de las tierras bajas del Caribe costarricense se describe y se ilustra en este artículo.

Licaria Aublet (Lauraceae) is a Neotropical genus of trees represented in Costa Rica by at least eight species, some of them very poorly understood (Burger \& van der Werff, 1990). It is well characterized by its androecium of three stamens with two thecae each and the deeply cupulate fruiting receptacle with two usually distinct margins on its rim. An additional species from the Caribbean lowlands is described below.

Licaria caribaea Gómez-Laurito \& Cascante, sp. nov. TYPE: Costa Rica. Limón: Límite norte del Parque Nacional Tortuguero, Caño Suerte, $9^{\circ} 36^{\prime} 42^{\prime \prime} \mathrm{N}, 83^{\circ} 45^{\prime} 00^{\prime \prime} \mathrm{W}, 0-10 \mathrm{~m}, 2$ set. 1995 (fl, fr), A. Cascante \& A. Ruíz 705 (holotype, $\mathrm{CR}$; isotypes, F, MO, USJ). Figure 1.

Species inflorescentia paniculata usque $32 \mathrm{~cm}$ longa, multiflora; stamina 2-locellata, locellis extrorsis, apicalibus; cupula late conica, usque $42 \mathrm{~mm}$ longa, longitudinaliter cristata a congeneribus diversa.

Trees 12-15 m tall, 20-30 cm DBH; bark lenticellate; inner bark yellowish, hard; leafy branchlets minutely puberulous, grayish, solid, terete. Leaves alternate; petioles 10-20 mm long, sulcate above, glabrous; leaf blades 18-24 cm long, 8-11 $\mathrm{cm}$ broad, ovate-elliptic, tapering to an acuminate apex, obtuse at the base, drying chartaceous and brownish green, glabrous on both surfaces, with 810 major secondary veins on each side, margin entire. Inflorescences paniculate, axillary and extraaxillary to distal leaves, 13-18(-32) cm long, 14$16 \mathrm{~cm}$ wide, many-flowered, minutely puberulous, peduncles 5-12 cm long, 1.5-2 $\mathrm{mm}$ thick with al- ternating lateral branches, tertiary branches 6-20 mm long, crowded by $6-9$ flowers on pedicels $2-4$ $\mathrm{mm}$ long. Flowers yellow, drying dark, 2-2.2 mm long, 6 tepals, externally very short puberulous, internally villous with whitish hairs; 3 fertile stamens, $1 \mathrm{~mm}$ long, strongly connivent forming a thick column, filaments not differentiated, anthers ovoid with 2 apical thecae and the small $(0.25 \mathrm{~mm})$ valves with extrorse dehiscence near the apex of the stamen; staminodes and glands minute, $0.3-0.5$ mm long, tightly pressed together and appearing fused; ovary narrowly ovate, glabrous, pistil $1 \mathrm{~mm}$ long, glabrous, style slender, simple, slightly exserted between the fertile stamens. Fruits borne on a broadly conical receptacle $31-42 \mathrm{~mm}$ long, 15$30 \mathrm{~mm}$ broad at the top, ca. $18 \mathrm{~mm}$ deep, longitudinally ridged, with two distinct margins on its rim, lenticellate, green turning red; fruiting pedicels 5-20 mm long, 3-4 mm diam.; berry narrowly ovoid to ellipsoid, $20-25 \mathrm{~mm}$ long, $10 \mathrm{~mm}$ diam., red to purple at maturity.

Licaria caribaea is currently known only from the Caribbean coastal plain of Costa Rica (hence its name), from 0 to $10 \mathrm{~m}$ elevation. It is found in the very wet forest commonly called "yolillales," "Tropical, tropical, very wet with no dry months" biotic unit according to Herrera and Gómez (1993). This new species is associated with Raphia taedigera Martius (Arecaceae), Carapa guianensis Aublet (Meliaceae), and the legumes Pentaclethra macroloba (Willdenow) Kuntze, Prioria copaifera Grisebach, and Crudia acuminata Bentham, among others. According to Kurz (1982), this new taxon belongs to his subgenus Guianensis (which he should have named subg. Licaria, because the type of the genus is included in the subgenus, according to van der Werff, in litt., 1996) and keys to $L$. excelsa Kostermans. Kurz's description of L. excelsa is rather broad; however, the two species can be readily separated by the following key:

Novon 9: 199-201. 1999. 


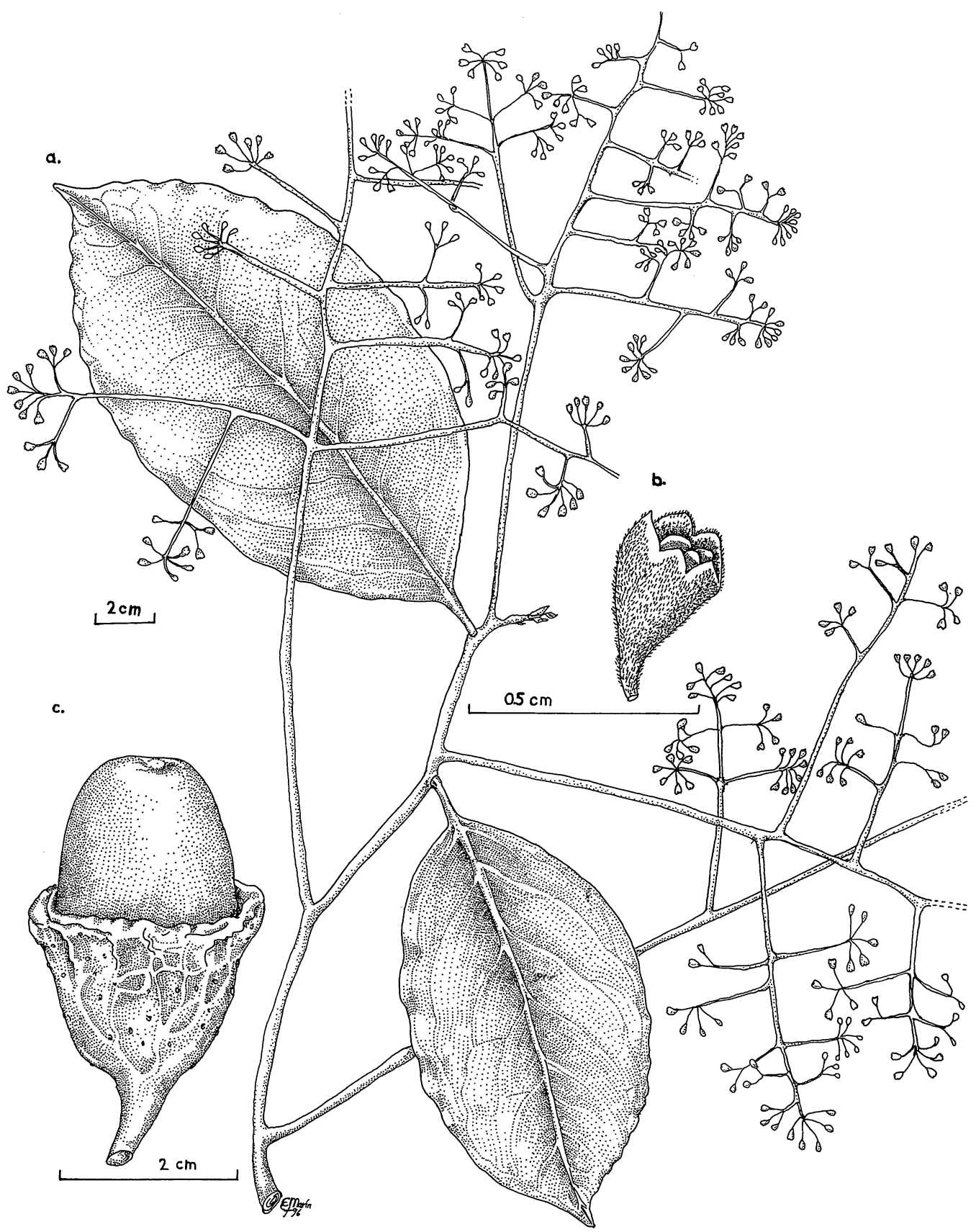

Figure 1. Licaria caribaea Gómez-Laurito \& Cascante (A. Cascante \& A. Ruiz 705). —a. Flowering branch. —b. Flower. -c. Fruit.

la. Trees of medium- to high-altitude habitat,(600-) 1100-2300 m; leaves drying dark in color; inflorescences $5-20 \mathrm{~cm}$ long; fruits borne in a cupulate or hemispherical receptacle $13-20 \mathrm{~mm}$ long, $18-12 \mathrm{~mm}$ broad, not ridged ..... . L. excelsa

1b. Trees of low-altitude habitat, 0-10 m; leaves drying brownish green in color; inflorescences 13$32 \mathrm{~cm}$ long, many-flowered; fruits borne in a broadly conical receptacle 31-42 mm long, 15-

$30 \mathrm{~mm}$ broad, longitudinally ridged ... L. caribaea

Paratypes. COSTA RICA. Limón: same locality as type, 3 Mar. 1996 (ster.), A. Cascante \& P. Opay 987 (CR, USJ), 3 Mar. 1996 (ster.), A. Cascante \& P. Opay 986 (CR, USJ), 3 Mar. 1996 (fr), A. Cascante \& P. Opay 985 (CR, USJ). 
Acknowledgments. We are grateful to Henk van der Werff (MO) and to William C. Burger (F) for critically reading the manuscript, and to Carmen Marín for the illustration. We also thank the Canadian Organization for Tropical Education and Rainforest Conservation (COTERC) for its support during field trips to Caño Palma Biological Station.

\section{Literature Cited}

Burger, W. C. \& H. van der Werff. 1990. Flora costaricensis. Family \#80, Lauraceae. Fieldiana Bot. New Ser. 23: 1-129.

Herrera, W. \& L. D. Gómez. 1993. Mapa de unidades bióticas de Costa Rica. Escala 1:685.000. Instituto Geográfico de Costa Rica.

Kurz, H. 1982. Fortpflanzungsbiologie einiger Gattungen neotropischer Lauracean und Revision der Gattung $L i$ caria (Lauraceae). Ph.D. Thesis, Universität Hamburg. 